Mineralogical Journal, Vol. 7, No. 3, PP. 289-297, OCT., 1973

\title{
The structure of hopeite
}

\author{
AKIRA KAWAHARA \\ Department of Earth Science, Science Faculties, \\ Okayama University, Tsushima, Okayama 700 \\ YUKIO TAKANO \\ Department of Pure and Applied Sciences, College of General \\ Educations, University of Tokyo, Komaba, \\ Meguro-ku, Tokyo 153 \\ and \\ MICHITOMO TAKAHASHI \\ Institute for Medical and Dental Research, Tokyo Medical \\ and Dental University, 10-3-2 Kandasurugadai \\ Chiyoda-ku, Tokyo 101
}

\begin{abstract}
The structural investigation of hopeite $\mathrm{Zn}_{3}\left(\mathrm{PO}_{4}\right)_{2} \cdot 4 \mathrm{H}_{2} \mathrm{O}$ was made by using three dimensional data measured with a single crystal diffractometer. The revised structure of hopeite differs from that reported by previous. authors and is considered to be derived from the structure of phosphophyllite by polysynthetic twinning of its unit cells.
\end{abstract}

\section{Introduction}

The structural investigation of hopeite $\mathrm{Zn}_{3}\left(\mathrm{PO}_{4}\right)_{2} \cdot 4 \mathrm{H}_{2} \mathrm{O}$ was. carried out for the first time by Mamedov, Gamedov and Belov in 1961, and its cell dimensions, space group and structural framework were described. Later, a revised model of the structure was proposed by Liebau (1962) on the basis of two dimensional investigations, and its cell dimensions and symmetry of coordination octahedra around $\mathrm{Zn}$ and $\mathrm{Fe}$ were compared with those of phosphophyllite $\left(\mathrm{Zn}_{2} \mathrm{Fe}\left(\mathrm{PO}_{4}\right)_{2} \cdot 4 \mathrm{H}_{2} \mathrm{O}\right)$. This structure was discussed again by Liebau in 1965. On the other hand, the structure of parahopeite, a di- 
morphous form of hopeite, was determined by Kumbasar and Finney (1968) and refined by Chao (1969). The relationship between $\alpha$ - and $\beta$-forms of hopeite were discussed by Takahashi, Kawahara and Takano (1972), and a new structure of hopeite was proposed. This new structure was tentatively named as $\beta$-hopeite. The refinement of the new structure of hopeite has been carried out in order to ascertain whether this new structure is really a new form of hopeite or the structure determined by Liebau is not correct. A twinning relationship between the structures of hopeite and phosphophyllite was found and is discussed in this paper.

\section{Experiment}

Platy crystals of hopeite were obtained by a slow titration of acidic solution of tri-sodium phosphate into $30 \mathrm{gr}$. of zinc sulphate dissolved in $2500 \mathrm{cc}$ of water, where the chemical reaction took place at about $20^{\circ} \mathrm{C}$ under the atmospheric pressure. Fairly large crystals (about $1 \mathrm{~mm}$ along the longest edge) were obtained and they were colourless, platy and elongated along $c$-axis, while its length along the $b$-axis is the shortest. The crystals thus obtained were identified as hopeite by the $\mathrm{X}$-ray powder diffraction method with reference to A.S.T.M. files. Because this synthetic condition for our present specimen was the same as for those specimens used in the study by Takahashi et al. and in the thermal investigation by Kawahara et al. (1972), it is certain that we have always dealt with the specimens of one and the same character. In our previous studies, we identified the specimens to be the $\beta$-form of hopeite. But in our present structural studies, we have arrived at the conclusion that there is no substantial difference between $\alpha$ - and $\beta$-form.

The intensity data and cell dimensions were measured with a Rigaku automated four-circle diffractometer made available by the courtesy of Prof. Y. Iitaka, Department of Pharmaceutical Sciences, University of Tokyo. The crystal data are: $\mathrm{Zn}_{3}\left(\mathrm{PO}_{4}\right)_{2} \cdot 4 \mathrm{H}_{2} \mathrm{O}$, 
orthorhombic, $a=10.553 \pm 0.002 \AA, b=18.199 \pm 0.004 \AA, c=5.031 \pm 0.001 \AA$, $\mathrm{V}=975.4 \AA^{3}, \mu=74 \mathrm{~cm}^{-1}$ Mo $K \alpha(\lambda=0.70926 \AA)$, space group, $\mathrm{D}_{2 \mathrm{~h}}^{16}-$ Pnma.

A crystal with dimensions of $0.3 \times 0.08 \times 0.3 \mathrm{~mm}$ was mounted with the $c$-axis parallel to the $\phi$ axis of the diffractometer. Mo $K \alpha$ radiation was used with balanced filters. The $2 \theta$-scan technique was employed at the rate of $2^{\circ}$ per minute. In total 1779 reflections were measured up to $2 \theta=70^{\circ}$. The reflections with $F_{\text {o }}$ less than 8.0 were regarded as unobserved in view of the accuracy of measurements. Lorentz and polarization factor corrections were made, and the correction for absorption was also carried out by the program "ACACA" by Wuensch and Prewitt registered in the file of the Computer Center of Osaka University made available by the courtesy of Prof. N. Morimoto and his collaborators. From the three-dimensional intensity data, Patterson syntheses were made and the position of $\mathrm{Zn}$ and $\mathrm{P}$ were found in the map. The positions of oxygen atoms were then determined from $\left(F_{o}-F_{\mathrm{c}}\right)$ Fourier maps with the phases given by $\mathrm{Zn}$ and $\mathrm{P}$ atoms. Then, the parameters of all atoms determined by Patterson and difference Fourier methods were refined with a diagonal least-squares program and the residual was reduced to 0.08 . The atomic parameters thus obtained are

Table 1. Positional parameters, temperature factors $\left(\AA^{2}\right)$ and the standard deviations of atomic parameters in parentheses.

\begin{tabular}{cllll}
\hline Atoms & \multicolumn{1}{c}{$x$} & \multicolumn{1}{c}{$y$} & \multicolumn{1}{c}{$z$} & \multicolumn{1}{c}{$\boldsymbol{c}$} \\
\hline $\mathrm{Zn} 1$ & $0.26384(19)$ & 0.25 & $0.4277(4)$ & $1.08(2)$ \\
$\mathrm{Zn} 2$ & $0.14295(11)$ & $0.00072(7)$ & $0.2934(5)$ & $0.87(2)$ \\
$\mathrm{P}$ & $0.39705(25)$ & $0.09448(15)$ & $0.2751(5)$ & $0.87(2)$ \\
O1 & $0.3028(8)$ & $0.0411(4)$ & $0.1318(15)$ & $1.02(4)$ \\
O2 & $0.5252(7)$ & $0.0785(4)$ & $0.1334(16)$ & $1.43(4)$ \\
O3 & $0.3611(8)$ & $0.1728(4)$ & $0.2133(18)$ & $1.63(4)$ \\
O4 & $0.3994(8)$ & $0.0807(5)$ & $0.5691(20)$ & $2.01(4)$ \\
O5 & $0.1633(8)$ & $0.1690(5)$ & $0.6602(18)$ & $1.98(4)$ \\
O6 & $0.3922(12)$ & 0.25 & $0.7409(28)$ & $1.87(4)$ \\
O7 & $0.1136(12)$ & 0.25 & $0.1565(27)$ & $2.11(4)$ \\
\hline
\end{tabular}


Table 2. Interatomic distances and angles calculated.

\begin{tabular}{|c|c|c|c|c|c|c|}
\hline \multicolumn{2}{|c|}{$\mathrm{Zn} 1-\mathrm{O} 3$} & \multicolumn{2}{|c|}{ 2. 04(1) $\AA$} & \multicolumn{3}{|c|}{$\mathrm{Zn} 2-\mathrm{O} 1^{1.94(1) \AA}$} \\
\hline$-c$ & & \multicolumn{2}{|c|}{$2.22(1)$} & \multicolumn{3}{|c|}{$\begin{array}{ll}-01^{\prime} & 2.09(1)\end{array}$} \\
\hline & $6\left(\mathrm{H}_{2} \mathrm{O}\right)$ & \multicolumn{2}{|l|}{$2.09(1)$} & \multicolumn{3}{|c|}{$-\mathrm{O} 2 \quad 1.87(1)$} \\
\hline & $7\left(\mathrm{H}_{2} \mathrm{O}\right)$ & \multicolumn{2}{|l|}{ 2. 24(1) } & \multicolumn{3}{|c|}{$-\mathrm{O} 4 \quad 1.88(1)$} \\
\hline $\mathrm{O} 3-\mathrm{Zr}$ & $1-\mathrm{O} 3$ & \multicolumn{2}{|c|}{$87.5(1.4)^{\circ}$} & $\mathrm{O} 1-\mathrm{Zn} 2-\mathrm{O}^{\prime}$ & $-01^{\prime}$ & $7(1.4)^{\circ}$ \\
\hline O5- & $-\mathrm{O}^{\prime}$ & \multicolumn{2}{|c|}{$88.6(1.4)$} & $\mathrm{O} 1-$ & $-\mathrm{O} 2 \quad 112.1$ & $1(1.4)$ \\
\hline O3- & -06 & \multicolumn{2}{|c|}{$92.3(1.4)$} & $\mathrm{Ol}-$ & $-04 \quad 104.5$ & $5(1.4)$ \\
\hline $\mathrm{O} 3-$ & -07 & \multicolumn{2}{|c|}{$91.9(1.4)$} & $\mathrm{O} 1^{\prime}-$ & $-04 \quad 112.0$ & $0(1.4)$ \\
\hline O5- & -06 & \multicolumn{2}{|c|}{$85.6(1.4)$} & $\mathrm{O} 2-$ & -O1' 108.7 & $7(1.4)$ \\
\hline O5- & -07 & \multicolumn{2}{|c|}{ 89. $2(1.4)$} & & & \\
\hline O5-O6 2. & $33(2) \AA$ & \multicolumn{2}{|c|}{ O5-O5 3.07(2) $\AA$} & $\mathrm{O} 1-\mathrm{O}^{\prime} 12.87(2) \AA$ & $\AA \quad \mathrm{O} 1-\mathrm{O} 4$ & $3.02(2) \mathrm{A}$ \\
\hline O5-O7 3. & $13(2)$ & \multicolumn{2}{|c|}{$\mathrm{O} 3-053.09(2)$} & $\mathrm{O} 1-\mathrm{O} 23.16(2)$ & $\mathrm{O} 2-\mathrm{O} 4$ & 3. $26(2)$ \\
\hline $\mathrm{O} 3-\mathrm{O} 62$ & $98(2)$ & \multicolumn{2}{|c|}{$\mathrm{O} 3-\mathrm{O} 32.85(2)$} & $04-0^{\prime} 13.16(2)$ & $\mathrm{O} 2-\mathrm{O}^{\prime} 1$ & (3. $22(2)$ \\
\hline \multicolumn{7}{|c|}{$\mathrm{O} 3-073.08(2)$} \\
\hline \multicolumn{3}{|c|}{$\mathrm{P}-\mathrm{O} 1 \quad 1.50(1) \AA$} & $\mathrm{O} 1-\mathrm{O} 2$ & 2. $41(2) \AA$ & \multicolumn{2}{|c|}{$\mathrm{O} 2-\mathrm{O} 3 \quad 2.48(2) \AA$} \\
\hline $\mathrm{P}-\mathrm{O} 2$ & \multicolumn{2}{|l|}{ 1. $55(1)$} & $\mathrm{O} 3-\mathrm{O} 42$. & 2. $47(2)$ & \multicolumn{2}{|c|}{$\mathrm{O} 1-\mathrm{O} 4 \quad 2.52(2)$} \\
\hline $\mathrm{P}-\mathrm{O} 3$ & \multicolumn{2}{|c|}{ 1. $54(1)$} & $\mathrm{O} 1-\mathrm{O} 32$ & 2. $52(2)$ & \multicolumn{2}{|c|}{$\mathrm{O} 2-\mathrm{O} 4 \quad 2.55(2)$} \\
\hline $\mathrm{P}-\mathrm{O} 4$ & $1.52(1)$ & & & & & \\
\hline $\mathrm{O} 1-\mathrm{P}-\mathrm{O} 2$ & 104. 3( & $(1.6)^{\circ}$ & $\mathrm{O} 1-\mathrm{O} 2$ & $22.41(2) \AA$ & $\mathrm{O} 2-\mathrm{O} 3$ & 2. $48(2) \AA$ \\
\hline $\mathrm{O} 1-\mathrm{P}-\mathrm{O} 3$ & 112.00 & (1.6) & $\mathrm{O} 3-\mathrm{O} 4$ & $4 \quad 2.47(2)$ & $\mathrm{O} 1-\mathrm{O} 4$ & $2.52(2)$ \\
\hline $\mathrm{O} 1-\mathrm{P}-\mathrm{O} 4$ & 113.11 & (1.6) & $\mathrm{O} 1-\mathrm{O} 3$ & $3 \quad 2.52(2)$ & $\mathrm{O} 2-\mathrm{O} 4$ & 2. $55(2)$ \\
\hline $\mathrm{O} 2-\mathrm{P}-\mathrm{O} 3$ & 106.8( & (1.6) & & & & \\
\hline $\mathrm{O} 2-\mathrm{P}-\mathrm{O} 4$ & 112.3( & (1.6) & & & & \\
\hline $\mathrm{O} 3-\mathrm{P}-\mathrm{O} 4$ & 107.7( & & & & & \\
\hline
\end{tabular}

shown in Table 1. The interatomic distances and bond-angles for nearest neighbours are also given in Table 2.

Throughout the present study, the calculations were carried out on a FACOM 230-60 computer in Kyushu University using the program UNICS, and also on a NEAC 2200-700 computer in Osaka University.

\section{Result}

In the structure thus determined (Fig. 1a), each of the $\mathrm{Zn}$ atoms in a mirror plane is surrounded in an octahedral coordinations by 
six anions, two of which are sheared, each by a tetrahedrally coordinated phosphorus atom and are therefore oxygen atoms, the remaining four being considered to be water molecules. The other $\mathrm{Zn}$ atoms are tetrahedrally coordinated by four oxygen atoms. In the structure determined by Liebau (Fig. 1c), the positions of the zinc atoms with octahedral coordinations are almost identical to ours but the atomic arrangements in the tetrahedral coordinations around zinc and phosphorus atoms are different. The positions of the center of symmetry and two-fold screw axis are different in

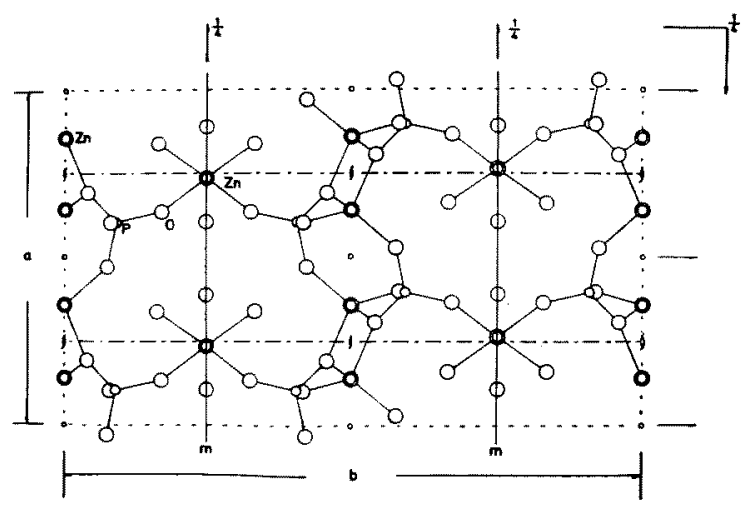

(a)

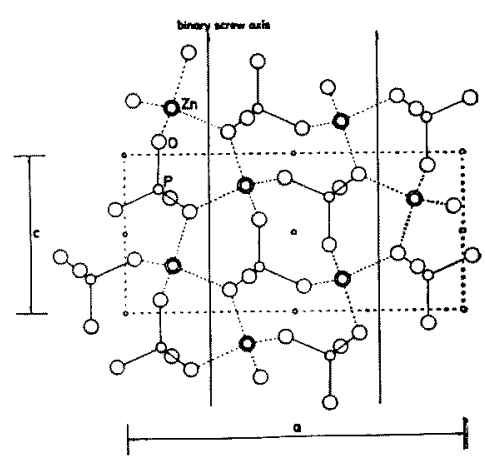

(b)

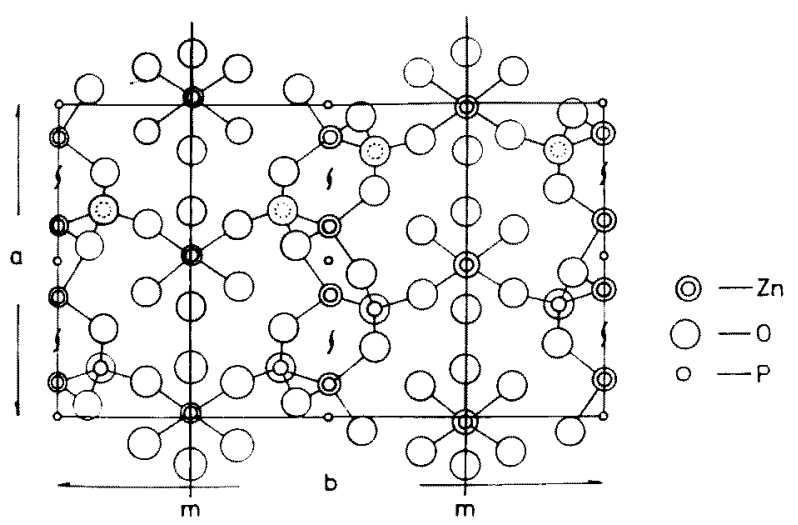

Fig. 1. Structure of hopeite.

(a) Projection parallel to $\mathrm{c}$.

(b) Section near a two-fold screw axis.

(c) Structure determined by Liebau. 
the two structure, and accordingly the directions of phosphorusoxygen and zinc-oxygen tetrahedra also differ. The linkage of tetrahedra is also shown in the Fig. 1b. The average $\mathrm{P}-\mathrm{O}$ distance observed is $1.53 \AA$. This value is in accordance fairly well with $1.54 \AA$ in parahopeite determined by Chao. The observed octahedral $\mathrm{Zn}-\mathrm{O}$ distances are in the range of $2.04-2.24 \AA$ in hopeite, while all the values are in $2.10-2.11 \AA$ in parahopeite.

\section{Discussions and conclusion}

The structural relationship between hopeite and phosphophyllite will be discussed here. First of all, the relationship between the cell dimensions of these minerals are as follows;

Hopeite $\mathrm{Zn}_{3}\left(\mathrm{PO}_{4}\right)_{2} \cdot 4 \mathrm{H}_{2} \mathrm{O}$

$$
\begin{aligned}
& a=10.553 \AA \\
& b=18.199 \AA \\
& c=5.031 \AA \\
& D_{2 h}^{16}-\text { Pnma }
\end{aligned}
$$

Phosphophyllite $\mathrm{Zn}_{2} \mathrm{Fe}\left(\mathrm{PO}_{4}\right)_{2} \cdot 4 \mathrm{H}_{2} \mathrm{O}$

$$
\begin{aligned}
& a=10.51 \AA \\
& b=5.09 \AA \\
& c=10.25 \AA \\
& \beta=120^{\circ} 15 \\
& C_{2 \mathrm{~h}}^{5}-P 2_{1} / a
\end{aligned}
$$

The $a$ edge of hopeite is nearly equal to the $a$ edge of phosphophyllite. Similarly, the $c$ edge is the same between two minerals and also $2 c \cdot \sin \beta$ in phosphophyllite is almost equal to the $b$ edge of hopeite. These geometrical relations in cell dimensions were discussed by Liebau (1965), together with the mode of symmetry around $\mathrm{Zn}$ and $\mathrm{Fe}$ atoms with octahedral coordinations. The twinning relationship between hopeite and phosphophyllite will be discussed below on the basis of the structure of hopeite newly investigated. Hopeite and phosphophyllite are considered to be dimorphous, because the mode of coordinations of Fe atoms is same as that of the $\mathrm{Zn}$ atoms in parahopeite, the dimorphous mineral of hopeite. The comparison of the mode of symmetry of octahedral $\mathrm{Zn}$ or Fe atoms among three minerals are shown in Fig. 2. 


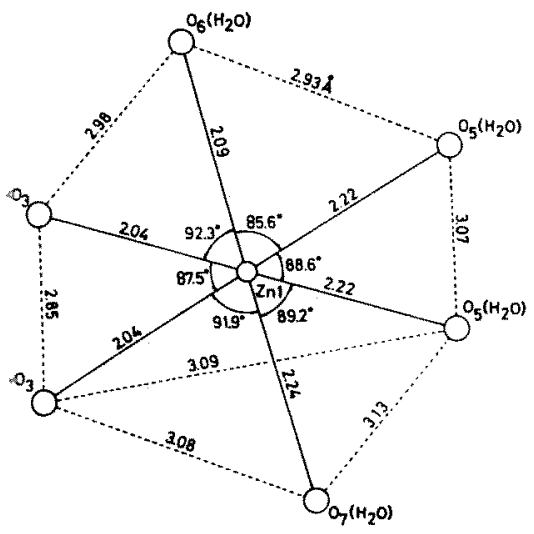

(a)

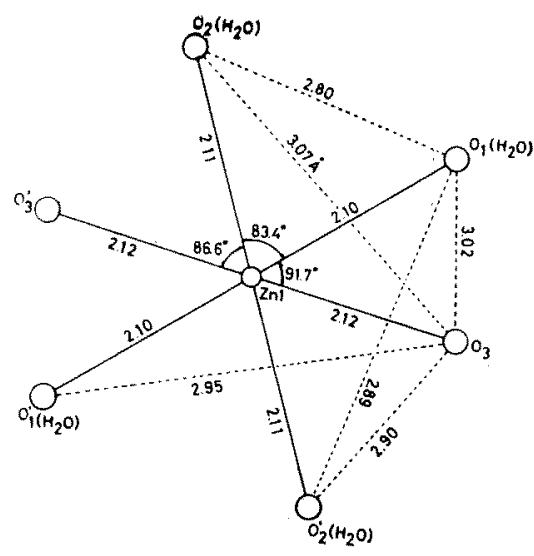

(b)

Fig. 2. Coordination octahedra around $\mathrm{Zn}$ or $\mathrm{Fe}$ atoms.

(a) $\mathrm{Zn}$ on a mirror plane (hopeite)

(b) $\mathrm{Zn}$ at a center of symmetry (parahopeite)

Fe of phosphophyllite takes the same coordination as that of parahopeite.

The structural relationship between phosphophyllite and hopeite are shown in Fig. 3. As shown in the figure, the detailed structure around the center of symmetry and two-fold screw axis of hopeite are almost the same as that of phosphophyllite. In fact, as shown in the Figs. 3a, b, the structure of hopeite can be interpreted as a microtwinning of the phosphophyllite unit cells. This relationship is in line with the submicroscopic twins given by Ito and his collaborators (1950) to explain the structural relationship between two dimorphous minerals. The structure of polymorphic forms of pyroxenes, amphiboles, epidotes, wollastonite, etc, were discussed by them in light of submicroscopic twins in the order of unit cells. The structural relation between hopeite and phosphophyllite can be tackled in the same way. The space group Pnma of hopeite can be derived by the twin of cells with the space group $P 2_{1} / a$ of phosphophyllite as shown in Fig. 3c. As the result of this twinning, 


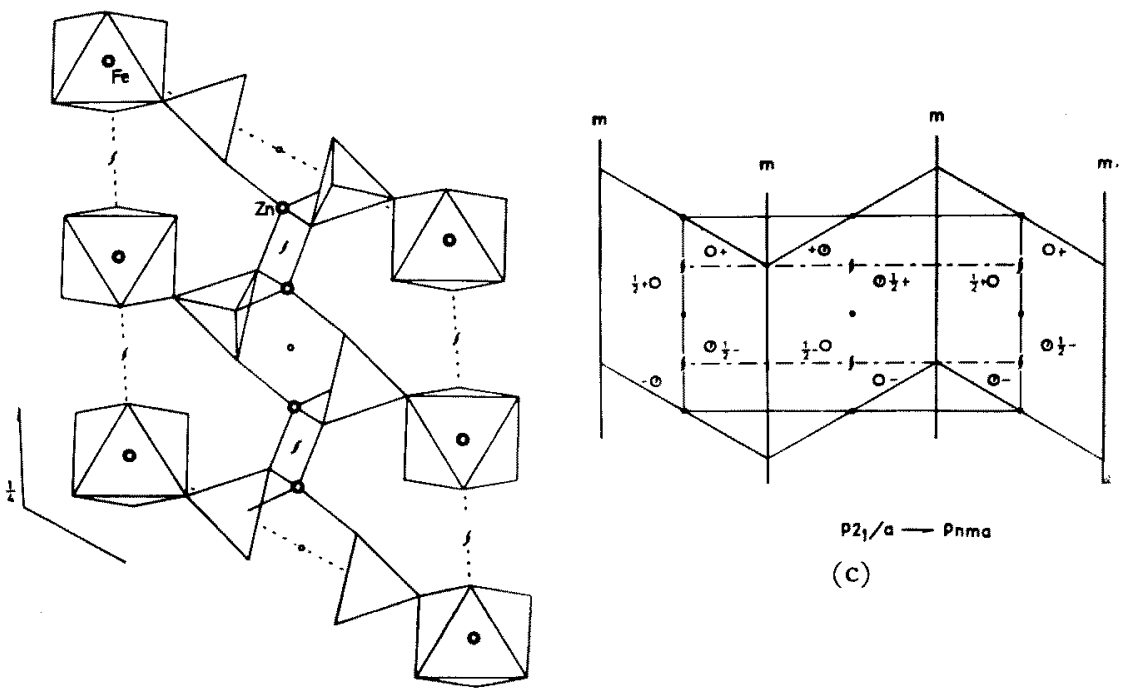

(a)

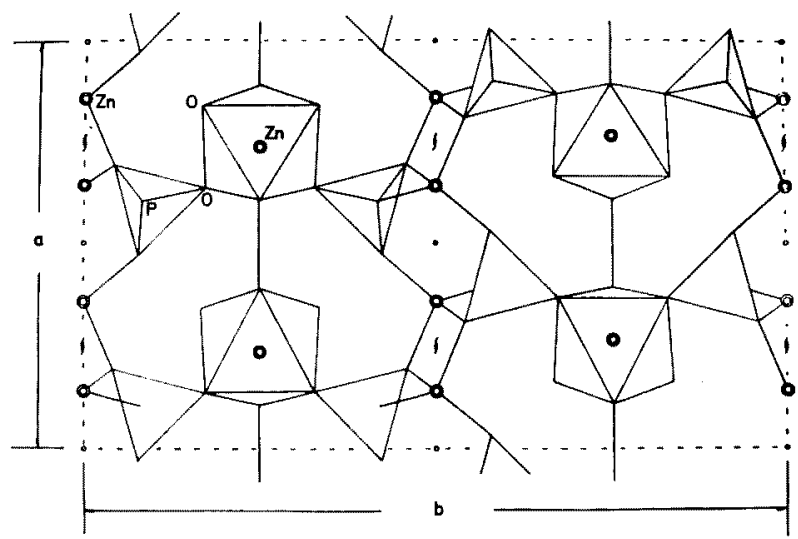

(b)

Fig. 3. Structural relationship between phosphophyllite and hopeite. The structure of hopeite (b) can be explained by the twin of the unit cells. of phosphophyllite (a). (c) Relation between the two space groups. 
the centers of symmetry and the two-fold screw axes on both sides of the unit cell of $P 2_{1} / a$ are replaced by mirror planes.

Thus the newly revised structure of hopeite is considered to be derived from the structure of phosphophyllite by polysynthetic twininning of its unit cells.

\section{REFERENCES}

CHAO, G. Y. (1969) Zeits. Krist., 130, 261.

ITo, T. (1950) X-ray studies on polymorphism, Maruzen Co., Ltd., Tokyo. Kleber, W., Liebau, F. \& Piatkowiak, E. (1961) Acta Cryst., 14, 795. Kawahara, A., Gan, K., Takahashi, M. \& Takano, Y. (1972) Sci. Pap.

Coll. Gen. Educ., Univ. Tokyo, 22, No. 2, 137.

Kumbasar, I. \& Finney, J. J. (1968) Miner, Mag., 36, 621.

Liebau, F. (1961) Acta Cryst., 14, 1103.

Liebau, F. (1962) Chem. der Erde, 22, 430.

Liebau, F. (1965) Acta Cryst., 18, 352.

Mamedov, C. S., Gamedov, R. G. \& Belov, N. W. (1961) Kristallogr. 6, 114. SakuraI, T. ed. (1971) Universal Crystallographic Computation Program System, Crystallographic Society of Japan.

Takahashi, M., Kawahara, A. \& Takano, Y. (1972) Acto, Cryst., A28, S4, S68.

Wuensch, B. J. \& Prewitt, C. T. (1965) Zeits. Krist. 122, 24.

Received July 7, 1973; revised September 6, 1973 